\title{
A mistagogia profética do Papa Francisco: uma análise litúrgico-sacramental dos atos simbólicos realizados pelo Papa Francisco
}

\author{
Prophetic mystagogy of the Pope Francis: \\ a liturgical-sacramental analysis of symbolic acts \\ performed by Pope Francis
}

Anderson Batista Monteiro

\section{Resumo}

O homem de hoje está cansado de ouvir discursos vazios, de modo que o testemunho de uma vida coerente com o Evangelho é a melhor forma de evangelizar. Desde a Sagrada Escritura, vemos que o anúncio da Palavra de Deus não é realizado somente por palavras, mas também por atos e gestos. $\mathrm{O}$ ministério de Jesus é marcado também por inúmeros atos proféticos que anunciavam que o Reino de Deus já se fazia presente. E da mesma forma, cristãos de todos os tempos impactaram e transformaram o mundo pela força do testemunho. Em continuidade com o testemunho profético da Igreja, este artigo quer investigar no pontificado do Papa Francisco, a natureza litúrgicosacramental de alguns de seus gestos, que possam contribuir para uma reflexão ainda mais profunda sobre o valor de seus atos neste pontificado. Podemos identificá-lo como um verdadeiro mistagogo, que conduz a Igreja do tempo presente para a vivência dos sagrados mistérios. E divididos em quatro eixos temáticos (missionário, solidário, ecumênico e ecológico) acreditamos ser possível extrair elementos para compreender as principais questões tratadas pelo Papa Francisco em chave litúrgico-sacramental.

Palavras-chave: Mistagogia. Sacramentos. Atos proféticos. Papa Francisco. 


\begin{abstract}
Contemporary's man is tired of listening to empty speeches, so the testimony of a life consistent with the Gospel is the best way to evangelize. Through the Holy Scripture, we see that the proclamation of the Word of God is not carried out only by words, but also by acts and gestures. Jesus' ministry is also marked by countless prophetic acts that announced that the Kingdom of God was already present. And in the same way, Christians of all times have impacted and transformed the world through the power of witness. Continuing with the prophetic testimony of the Church, this article is willing to investigate in the pontificate of Pope Francis, the liturgical-sacramental nature of some of his gestures, which may contribute to an even deeper reflection on the value of his acts in this pontificate. We can identify him as a true mystagogue, who leads the Church of the present time to live the sacred mysteries. And divided into four thematic axes (missionary, solidary, ecumenical and ecological) we believe it is possible to extract elements to understand the main issues addressed by Pope Francis in a liturgical-sacramental key.
\end{abstract}

Keywords: Mystagogy. Sacraments. Prophetic acts. Pope Francis.

\title{
Introdução
}

O pontificado do Papa Francisco é marcado desde o seu início por atos simbólicos que carregam consigo uma mensagem cheia de significados. Desde a sua eleição como bispo de Roma, que escolhendo o nome de Francisco e na primeira aparição como Papa, em que surpreende os fiéis reunidos da Praça de São Pedro ao se inclinar e pedir a oração de toda Igreja, já revela a predileção de Francisco por ações simbólicas como uma forma de transmitir sua mensagem. A cada momento, com gestos simples, o Papa surpreende o mundo que o escuta não pelos ouvidos, mas por aquilo que se vê. Podemos entender que o Papa Francisco coloca em prática aquilo que o Papa Paulo VI afirmava na Exortação Apostólica Evangelii Nutiandi sobre a evangelização no mundo contemporâneo em 1975. Para Paulo VI, o testemunho é mais valioso do que as palavras de um discurso, "o homem contemporâneo escuta com melhor boa vontade as testemunhas do que os mestres", e continua, pois "sabemos bem que 
o homem moderno, saturado de discursos, se demonstra muitas vezes cansado de ouvir e, pior ainda, como que imunizado contra a palavra". ${ }^{1}$

$\mathrm{Na}$ teologia bíblica, encontramos as ações simbólicas realizadas pelos profetas de Israel e por Jesus, como uma modalidade de pregação da Palavra de Deus. Estas ações estavam presentes nas pregações através de um ato concreto, que sobressaía diante da palavra, evidenciando a mensagem profética. Os atos proféticos tinham por objetivo anunciar a mensagem profética, visualizar a vontade de Deus, ser um sinal de conversão para o povo e projetar a realidade futura de Deus na história. ${ }^{2}$

As ações simbólicas dos profetas e de Jesus estão inseridas no plano da salvação, e por isso, não são apenas acontecimentos históricos, mas são atos histórico-salvíficos, dos quais originam os atos sacramentais da Igreja. O envolvimento da Igreja nascente nos atos proféticos de Cristo, permitiu que, pela força do Espírito Santo, os gestos e as palavras de Jesus rompessem a barreira do tempo para levar a graça e salvação a todos homens. Por sua vez, o homem interpelado pelo Eterno, por meio das ações sacramentais atinge o mistério e se encontra com Deus. Esta relação entre o homem e Deus pela liturgia sacramental transforma a história pessoal em vista da instauração do Reino de Deus.

É por esta perspectiva bíblico-litúrgica que consideramos os gestos do Papa Francisco, isto é, a partir das ações simbólicas dos profetas de Israel e de Jesus que foram prolongadas na Igreja no sinal visível dos sacramentos. A partir deste olhar teológico identificamos o caráter mistagógico de quem conduz seus ouvintes a uma experiência concreta com o mistério salvífico de Deus. Do mesmo modo, investigamos a natureza sacramental dos atos proféticos dentro da dinâmica responsorial do mistério celebrado e do mistério vivido que testemunha os valores do Reino de Deus.

Neste artigo, o nosso objetivo é fazer uma leitura litúrgico-sacramental de alguns atos simbólicos realizados pelo Papa Francisco em seu pontificado. Atos estes que surgem de uma profunda experiência com Cristo e com a força vital de seu significado, quer conduzir a Igreja e o mundo para uma profunda experiência com Cristo. Sem a pretensão de esgotar a temática, apresentaremos os atos de Francisco divididos em quatro eixos temáticos: missionário, solidário, ecumênico e ecológico, de forma que a percepção litúrgica destes atos contribua para a escuta do anúncio profético de Francisco e para o encontro transformador com mistério de Deus.

\footnotetext{
${ }^{1}$ EN 41-42.

${ }^{2}$ RAD, G., Teologia do Antigo Testamento, p. 530-531.
} 


\section{O retorno da mistagogia na prática evangelizadora da Igreja}

Diante da crise no processo de iniciação cristã, em um tempo no qual se observa o distanciamento entre fé e vida, a experiência do catecumenato é proposta pela Igreja como método catequético que conduza o fiel a vivenciar o mistério da salvação. Diferente de uma metodologia de catequese centrada no ensino de dogmas, mas que não alcança a vida das pessoas, o caminho mistagógico busca à luz da experiência litúrgica da Igreja dos séculos III e IV, orientar para uma vivência integral da espiritualidade cristã.

A mistagogia antiga é fruto da produção teológico-pastoral dos Padres da Igreja como Cirilo de Jerusalém, Ambrósio, Agostinho, João Crisóstomo e Teodoro de Mopsuéstia que desejavam conduzir os fiéis ao encontro com Jesus Cristo. $\mathrm{Na}$ época, correspondia às homilias para os neófitos pelos bispos durante a oitava da páscoa a fim de transmitir a relação entre a salvação e os ritos de iniciação cristã. ${ }^{3}$ Encontramos também obras patrísticas de cunho mistagógico fora do tempo da oitava da páscoa que versavam sobre temas litúrgicos e sobre a vida cristã. A mistagogia era a teologia dos Padres da Igreja de cunho histórico-salvífico, as ações litúrgicas eram os lugares da manifestação do mistério de Deus.

As catequeses mistagógicas consistiam na descrição do rito, dos gestos e das palavras, em relação ao evento salvífico. O mistagogo, apresentava a Escritura para fundamentar a celebração do rito estabelecendo a ligação entre o rito e a vida nova do cristão. Uma das características da Igreja patrística era de que a celebração litúrgica não estava fechada em si mesma, mas se realizava na vida cristã - lex orandi, lex credendi, lex agendi. ${ }^{4}$

Nos últimos decênios, com a reforma do catecumenato pedida pelos padres conciliares, o tema da mistagogia ressurge a fim de responder às necessidades pastorais do processo de iniciação cristã de nosso tempo. A publicação do Ritual de Iniciação Cristã de Adultos (RICA), em 1972, foi um divisor de águas no método de formação cristã. O processo catecumenal descrito no RICA indica uma atenção ao desenvolvimento humano-espiritual dos catecúmenos pela formação e pela celebração litúrgica. Uma das principais preocupações deste processo é o respeito ao amadurecimento no caminho de fé dos catecúmenos e catequizandos, que agora devem ser acompanhados por um

\footnotetext{
${ }^{3}$ SARTORE, D., Mistagogia, p. 1208-1209.

4 “A liturgia é, por conseguinte, práxis simbólica, isto é, ortopráxis profundamente unida à ortodoxia à medida que não se reduz à mera cerimônia ritual - já que expressa, atualiza e torna operativa a práxis pascal de Cristo" (FLORISTÁN, C., Pastoral litúrgica, p. 428).
} 
introdutor. Este processo é trilhado com um acompanhamento pessoal, de modo que as etapas da iniciação cristã vão de acordo com o crescimento humanoespiritual do candidato, em vista do seu compromisso com Deus, com o próximo e com o mundo.

A reforma dos ritos litúrgicos da Igreja buscou realizar uma passagem de uma teologia litúrgica alicerçada na teologia escolástica para um novo paradigma teológico de perspectiva bíblica e patrística, tal como foram as bases do Concílio Vaticano II. Desse modo, os livros litúrgicos foram reformulados na década de 60 e 70, mesmo que não tenha sido caracterizado um método mistagógico, é notável nas introduções gerais dos livros litúrgicos, na estrutura e conteúdo da celebração. ${ }^{5}$

No magistério pós-conciliar, a mistagogia como método catequético é recomendado durante o Sínodo extraordinário dos bispos em comemoração aos vinte anos do CVII no ano de 1985. Este Sínodo foi convocado por João Paulo II para verificar e promover as implementações conciliares na vida da igreja. No documento final, os padres sinodais relatam a necessidade de uma participação ativa na liturgia e para isso recomendam que: "as catequeses, como ocorria no início da igreja, devem voltar a ser um caminho que introduza na vida litúrgica - catequese mistagógica", e continua: "os futuros sacerdotes aprendam a vida litúrgica de forma prática e conheçam bem a teologia litúrgica" ${ }^{6}$ Dessa forma, as recomendações dos padres sinodais marcam início magisterial da pesquisa teológica sobre a mistagogia antiga e sua aplicação para a evangelização dos cristãos de hoje. ${ }^{7}$

Depois de 20 anos, Papa Bento XVI ao publicar a Exortação apostólica pós-sinodal Sacramentum Caritatis confirma a mistagogia como produção teológica e a indica como um itinerário de formação para toda comunidade eclesial e não somente como uma etapa do RICA. Além disso, Bento XVI descreve os três elementos principais da mistagogia: a interpretação dos ritos à luz do mistério salvífico, a compreensão do fiel sobre os sinais presentes nas celebrações litúrgicas, e a relação entre o rito celebrado e a vida cristã. ${ }^{8}$

Outro documento magisterial que ressalta a importância da mistagogia para os dias atuais foi publicado pelo Papa Francisco em 2013, a Exortação Apostólica Evangelii Gaudium, sobre o anúncio do Evangelho no mundo atual, destaca o querigma e a mistagogia como partes importantes do processo de

\footnotetext{
5 TRIACCA, A. M., Rinnovamento litúrgico, p. 1657.

${ }^{6}$ SINODO DEI VESCOVI, Relazione finale del sinodo dei vescovi.

${ }^{7}$ BOSELLI, G., O sentido espiritual da liturgia. p. 25.

${ }^{8} \mathrm{SCa} 64$.
} 
formação cristã. Ressalta ainda a importância da formação de toda comunidade eclesial no processo de formação da pessoa humana e a centralidade da Palavra de Deus e a valorização dos sinais litúrgicos da iniciação cristã. ${ }^{9}$

Papa Francisco retoma o tema da mistagogia em seu discurso aos participantes da assembleia plenária da Congregação para o Culto Divino e a disciplina dos Sacramentos em 2019. Ele enfatiza a necessidade da formação litúrgica do Povo de Deus orientado ao encontro com o "mistério vivo do Senhor" e indica a mistagogia como "um caminho idôneo para entrar no mistério da liturgia, no encontro vivo com o Senhor crucificado e ressuscitado". ${ }^{10}$

\section{A perspectiva litúrgico-sacramental das ações simbólicas dos profetas e de Jesus}

Como um pastor que quer testemunhar o encontro transformador com Cristo crucificado e ressuscitado na liturgia, Papa Francisco, a exemplo dos grandes mistagogos: Cirilo de Jerusalém, Ambrósio, Agostinho e outros já mencionados neste artigo, busca incansavelmente realizar sua missão não apenas com discursos, mas principalmente por atos. O pedido do Papa Paulo VI, para que o testemunho fosse prioridade na evangelização, ressoa no coração do Santo Padre. E assim, repetidamente chama a atenção não só da Igreja, mas de todo mundo pela eloquência expressiva de seus atos que falam mais do que inúmeras palavras.

Sendo assim, não podemos olhar como simples os gestos aparentemente espontâneos do Papa Francisco, mas sim como atos proféticos inseridos na dinâmica histórico-salvífica. ${ }^{11}$ Sobre isso, a teologia sacramental que estuda os sacramentos em chave de continuidade com os 'ôt proféticos do Antigo Testamento, ${ }^{12}$ oferece um contributo para uma abordagem sacramental dos atos simbólicos do Papa em uma perspectiva profético-mistagógico-sacramental.

\footnotetext{
${ }^{9}$ EG 166-167.

${ }^{10}$ FRANCISCO, PP., Discurso aos participantes na assembleia plenária da congregação para o culto divino e a disciplina dos sacramentos.

${ }^{11}$ A relação entre aos atos proféticos dos profetas e de Jesus e história da salvação é aprofundada na dissertação de mestrado do autor intitulada: MONTEIRO, A. B., Os sacramentos como continuação dos atos de Cristo na Igreja, desenvolvida no Programa de Pós-Graduação em Teologia da PUC-Rio. Esta seção do artigo retoma a dissertação de mestrado do autor.

12 Teólogos como Philip Rosato, Henry Mottu e Pedro Guimarães entendem que os sacramentos não são realidades "administradas", mas são mistérios celebrados que atualizam o evento salvador, carregam consigo uma natureza responsorial da dinâmica da revelação de Deus aos
} 
No Antigo Testamento, os profetas de Israel se utilizavam de "ações simbólicas" como meio de anúncio profético. A Sagrada Escritura utiliza o termo 'ôt no hebraico e semeîon no grego, traduzido como "sinal" para indicar que Deus fala e age no meio de seu povo. As ações simbólicas realizadas pelos profetas no Antigo Testamento trazem em si uma capacidade de atrair a atenção dos destinatários da mensagem, de forma mais expressiva do que a própria palavra. O biblista G. Von Rad reconhece a dificuldade em compreender o valor desses sinais como revelação divina. Foi preciso um longo tempo para que os exegetas reconhecessem o valor significativo dos sinais proféticos. ${ }^{13}$

As ações realizadas pelos profetas não eram simplesmente uma ilustração pedagógica da pregação, mas representavam um ato verdadeiramente profético. Por meio delas, os profetas comunicavam a mensagem divina. Isaías quando caminha descalço e nu durante três anos (Is 20,1-4) o faz como um sinal de que o Egito e Cuch (Etiópia) cairiam diante da Assíria e os prisioneiros seriam levados nus. Oséias ao acolher sua esposa adúltera (Os 3,1-3), que pela lei seria condenada à morte, expressa o perdão e o amor de Deus perante a traição de seu povo. E Jeremias depois de proferir um sermão contra Judá e Jerusalém, denunciando a idolatria que teria como consequência a queda dos Reinos, atira uma bilha de barro no chão que se quebra em pequenos pedaços (19,1-2a.10-11a) como um sinal da ruína das nações. ${ }^{14}$

Esses três exemplos de ações simbólicas realizadas pelos profetas de Israel denotam a natureza destes atos que carregam consigo uma grande expressão de significados. Por estes atos a vontade divina é realizada e produz uma realidade nova no mundo e fazem visualizar o anúncio salvífico de Deus. Além disso, os atos proféticos não apenas querem proclamar a vontade de Deus, mas também torná-la real. Deus se faz presente nos sinais proféticos com o propósito de comunicar o seu plano salvífico ao povo eleito. Por sua vez, este povo deve identificar nesses atos a presença de Deus, e em uma resposta à ação profética deve atender ao chamado para uma mudança de mentalidade e de comportamento em vista do cumprimento da aliança.

Jesus também se utiliza de atos proféticos que recordavam o modo de atuar dos profetas de Israel. Na verdade, era até mesmo reconhecido como um grande profeta por suas obras e palavras (Lc 24,19). O seu batismo no Jordão, o chamado dos doze apóstolos, as curas, os milagres, os exorcismos eram atos

homens (ROSATO, P., Introdução à teologia dos sacramentos; MOTTU, H., Il gesto e la parola; GUIMARÃES, P., Os sacramentos como atos eclesiais e proféticos.

${ }^{13}$ RAD, G., Teologia do Antigo Testamento. p. 531.

${ }^{14}$ ELLIS, P., Jeremias, p. 54. 
proféticos que anunciavam a chegado do Reino de Deus e antecipavam o cumprimento escatológico do Reino através de suas próprias ações. ${ }^{15}$ Os atos proféticos de Jesus marcaram de tal forma a vida dos seus discípulos, que a Igreja nascente após Pentecostes buscou continuar a mensagem profética da vinda do Reino.

O envolvimento contínuo dos cristãos nos atos proféticos de Jesus desenvolveu a liturgia sacramental como um acontecimento extraordinário na história pessoal. Pela ação do Espírito Santo que $a$ acompanha, a Igreja primitiva reconheceu os atos proféticos de Cristo como sinais do cumprimento escatológico que deviam ser celebrados na assembleia cristã e continuados na sociedade sob a forma de tarefas éticas. ${ }^{16}$ As palavras e as ações da última ceia em torno da páscoa judaica e do mistério pascal cristão, marcado pelo pedido: "Fazei isto em memória de mim", são vistos como ato profético da prefiguração do cumprimento do Reino a ser realizado entre a primeira e a última vinda de Cristo.

Nos primeiros séculos da Igreja, a espiritualidade eclesial era alicerçada na celebração dos mistérios de Cristo. Antes da formulação dogmática que foi se desenvolvendo ao longo dos séculos, os cristãos professavam a sua fé na liturgia e viviam no dia a dia de acordo com o que celebravam. Em síntese, eles vivenciavam aquilo que foi afirmado no Concílio Vaticano II: A liturgia é a fonte e o cume da vida cristã. ${ }^{17}$ Em continuidade com a teologia conciliar, para o Papa Francisco, a liturgia é viva pois nela habita o coração pulsante de Cristo, e por isso, gera uma Igreja viva que tem em seu núcleo o coração missionário de Cristo. ${ }^{18}$

\section{Os atos proféticos mistagógicos do Papa Francisco}

Conforme descrevemos neste trabalho, sob a ótica da teologia sacramental, os atos proféticos do Papa Francisco não são apenas uma força de expressão de um homem que necessita se comunicar com um mundo tão diverso e com tantas línguas, mas são atos inspirados pelo Espírito Santo, que o escolheu para conduzir a barca de Cristo. Os gestos simbólicos deste pontífice têm a sua fonte na celebração e vivência dos mistérios de Cristo e que reconhece a sua responsabilidade em prolongar estes gestos nos dias de hoje.

É nesta perspectiva profética que agora olhamos alguns gestos do pontificado do Papa Francisco como atos proféticos que traduzem na vida

\footnotetext{
${ }^{15}$ ROSATO, P., Introdução à teologia dos sacramentos, p. 53.

${ }^{16}$ ROSATO, P., Introdução à teologia dos sacramentos, p. 73

${ }^{17} \mathrm{SC} 10$.

${ }^{18}$ FRANCISCO, PP., Discurso aos participantes na $68^{\mathrm{a}}$ semana litúrgica nacional.
} 
aquilo que celebramos na liturgia. Francisco é um mistagogo que pela força dos sinais anuncia o mistério de Deus que transforma o homem de modo integral, a sua relação com Deus, consigo mesmo, e com o mundo. Como chave de interpretação litúrgica do pontificado de Francisco, elencamos quatro eixos temáticos recorrentes em seu magistério escrito e simbólico, conscientes de que outros temas importantes também foram ocupados por Francisco: missionário, solidário, ecumênico, inter-religioso e ecológico.

\subsection{Missionário}

O pontificado de Francisco é marcado por imagens simbólicas que expressam a dimensão missionária da Igreja. Para isso, ele utiliza a expressão "Igreja em saída", ${ }^{19}$ e explica que prefere uma "Igreja acidentada, ferida e enlameada por ter saído pelas estradas, a uma Igreja enferma pelo fechamento e a comodidade de se agarrar às próprias seguranças". ${ }^{20}$ As palavras que escolhe para designar a missão da Igreja se transformarão em gestos claros e objetivos em favor da conversão pastoral necessária para a evangelização nos dias de hoje. ${ }^{21}$

Um dos sinais de que deseja uma Igreja missionária, aconteceu na mudança de paradigma na escolha dos novos cardeais. A cada nomeação para o colégio cardinalício, Papa Francisco surpreende em abrir mão das tradicionais "sedes cardinalícias", para expressar a universalidade da Igreja. A Igreja missionária de Francisco é composta por muitos rostos. ${ }^{22}$ Por isso, pela primeira vez países como Tonga, Myanmar, Panamá, Cabo Verde e outros passaram a ter um representante no sacro colégio. ${ }^{23}$ Francisco busca a superação do centralismo na cúria romana, para que a Igreja deixe de ter uma tendência eurocêntrica, para ser nitidamente universal. R. Repolo observa que para Francisco a Igreja deve refletir o rosto do povo de Deus "que se encarna nos

19 EG 20. Sobre este termo "Igreja em saída", S. Pié-Ninot afirma que surge a partir do movimento de "saída" que Deus quer provocar nos crentes, como se vê nas vocações de Abraão, Moisés e Jeremias, e, em particular, na missão que Jesus confia aos seus discípulos, dizendolhes: "'Ide por todo o mundo, anunciai o Evangelho' (Mc 16; Mt 28)" (PIÉ-NINOT, S., La eclesiología del Papa Francisco, p. 263).

${ }^{20}$ EG 49.

21 "Com obras e gestos, a comunidade missionária entra na vida diária dos outros, encurta as distâncias, abaixa-se - se for necessário - até à humilhação e assume a vida humana, tocando a carne sofredora de Cristo no povo. Os evangelizadores contraem assim o 'cheiro das ovelhas', e estas escutam a sua voz" (EG 24).

${ }^{22}$ EG 115-118.

${ }^{23}$ MICKENS, R., Papa Francisco escolhe novos cardeais que vêm da periferia. 
diversos povos e se enriquece da sua cultura, sem, todavia, confundir-se e esgotar-se em nenhuma delas". ${ }^{24} \mathrm{Da}$ mesma forma, Francisco age profeticamente destacando o protagonismo dos leigos, não apenas nos documentos pontifícios, mas transformando a cúria romana que era predominantemente clerical. Por isso, ao reformar o Pontifício Conselho para a Comunicação, e criar o Dicastério para a Comunicação, nomeia como prefeito o jornalista Paolo Ruffini.

Para o Santo Padre, a Igreja não pode estar centrada nela mesma, mas encontra o seu sentido e a sua existência no anúncio da misericórdia de Deus. Por isso, o centro de sua pregação é a misericórdia, o coração do Evangelho, ${ }^{25}$ que revela a plenitude do mistério de Cristo que deve ser anunciado e testemunhado pela Igreja na vida de cada cristão. A grandiosidade da misericórdia de Deus é expressa pelo Papa na convocação de um jubileu extraordinário da Misericórdia. $\mathrm{O}$ jubileu, que acontece a cada vinte e cinco anos como um tempo de paz e de reconciliação, foi convocado de modo extraordinário por meio da Bula Misericordiae Vultus (O Rosto da Misericórdia) para o período de dezembro de 2015 a novembro de 2016 como um sinal profético do anúncio da misericórdia de Deus para o mundo.

W. Kasper enfatiza que "misericórdia" é a palavra-chave deste pontificado. ${ }^{26}$ A Igreja tem a missão de ser o sinal da Misericórdia de Deus no mundo, "onde todos podem se sentir acolhidos, amados, perdoados e animados a viverem segundo a vida boa do Evangelho (EG 114)". ${ }^{27}$ Para isso, não bastam apenas palavras, mas a misericórdia precisa ser traduzida em obras. E por isso, na Bula de proclamação do Jubileu o Papa Francisco recomenda a prática das obras de misericórdia como uma "maneira de acordar a nossa consciência, muitas vezes adormecida perante o drama da pobreza", de modo que ao encontro dos "mais pequeninos" encontraremos o próprio Cristo. Estes gestos de misericórdia também podemos chamá-los de gestos de solidariedade. ${ }^{28}$

\subsection{Solidário}

Para Francisco, a solidariedade da Igreja nasce da Eucaristia. Na última ceia, Jesus se entrega totalmente como pão da vida para todos os homens. E na

\footnotetext{
${ }^{24}$ REPOLE, R., O sonho de uma Igreja evangélica, p. 48.

${ }^{25} \mathrm{MV} 12$

${ }^{26}$ KASPER, W., La sfida della misericordia, p. 17-22.

${ }^{27}$ CASULA, L., Rostos, gestos e lugares, p. 55.

${ }^{28}$ MV 15.
} 
fragilidade do pão eucarístico "transborda amor e partilha". ${ }^{29}$ Para ele, a Eucaristia nos lembra que "é urgente cuidar de quem tem fome de alimento e dignidade, de quem não trabalha e tem dificuldade em seguir para diante". Como gesto profético que visualiza a fragilidade do Corpo de Cristo e se faz solidário com os que sofrem, Francisco transfere a Missa da Ceia do Senhor da Basílica São João de Latrão, para presídios, centros de detenção para menores infratores, hospitais e abrigos de refugiados. Com o gesto litúrgico de lavar os pés, o Papa foi ao encontro dos mais frágeis, para que diante deles expressasse a presença do Cristo servidor em suas vidas. ${ }^{30}$

Além disso, o ritual que previa que apenas homens fossem escolhidos para o lava-pés foi modificado para que homens e mulheres, jovens e idosos, sadios e enfermos, leigos e consagrados fossem escolhidos para representar a totalidade do povo de Deus. ${ }^{31}$ Mas Francisco vai além e na prisão inclui mulçumanos, judeus e budistas. Como observa L. Casula, para o Papa: "Na Eucaristia, a fragilidade é força; força do amor que se faz frágil para poder ser recebido. Força do amor que se divide para alimentar, dar vida e ser partilhada de modo solidário". ${ }^{32}$

Na Evangelii Gaudium, o Pontífice deseja uma Igreja que saia da sua comodidade e vá ao encontro das periferias existenciais do mundo (EG 20), enfatiza a dimensão social da evangelização de "uma igreja pobre para os pobres, capaz de aprender dos pobres". ${ }^{33}$ L. Casula afirma que para Francisco os pobres são "uma categoria teológica que nos permite conhecer a Deus, ver o rosto de Cristo e compreender a mensagem evangélica". ${ }^{34}$ Tradicionalmente, a Esmolaria Apostólica é um departamento da cúria romana responsável por realizar as obras de caridade da Igreja. Com recursos provenientes da emissão de bênçãos apostólicas através de pergaminhos e de outras doações, ajuda em nome do Papa os que mais necessitam. Francisco, ao nomear o arcebispo polonês Konrad Krajewski, reestrutura e dinamiza o serviço do esmoleiro conforme a necessidade do tempo presente. O jornalista Sergio Centofanti relata as atividades da esmolaria com as seguintes palavras:

${ }^{29}$ CASULA, L., Rostos, gestos e lugares, p. 37

${ }^{30}$ TABORDA, F., Uma eucaristia viva para uma Igreja viva, p. 114.

${ }^{31}$ CONGREGAÇÃO PARA O CULTO DIVINO E A DISCIPLINA DOS SACRAMENTO, Decreto In Missa In Cena Domini.

${ }^{32}$ CASULA, L., Rostos, gestos e lugares, p. 37.

${ }^{33}$ EG 198.

${ }^{34}$ CASULA, L., Rostos, gestos e lugares, p. 67. 
A Esmolaria realiza todos os dias, em silêncio, sua atividade: sustenta refeitórios para os pobres, administra um ambulatório médico-sanitário sob a Colunata de Bernini, dedicado à "Mãe da Misericórdia", juntamente com os chuveiros e a barbearia para os sem-teto, além do dormitório na Via dei Penitenzieri, pertinho do Vaticano. O atual Esmoler, cardeal Konrad Krajewski, é considerado "o braço da caridade do Papa". Sua principal tarefa - diz - é "esvaziar a conta do Santo Padre para os pobres, segundo a lógica do Evangelho". ${ }^{35}$

A primeira visita apostólica de Francisco também foi um ato profético de solidariedade. Em 8 de julho de 2013, Francisco sai de Roma para celebrar a Eucaristia na ilha de Lampedusa, no sul da Itália, no mar Mediterrâneo. Lampedusa se tornara o centro de uma crise humanitária com a vinda de milhares de refugiados vindos da África e das regiões de conflitos; milhares morreram no Mediterrâneo em busca de uma melhor condição para viver. Ele mesmo afirma que sua visita "foi para cumprir um gesto de solidariedade, mas também para despertar as nossas consciências a fim de que não se repita o que aconteceu". ${ }^{36} \mathrm{E}$ em 2015 o fluxo imigratório alcançou números recordes, e tornou-se a maior crise humanitária enfrentada pela Europa desde a Segunda Guerra Mundial. Nesta ocasião, em setembro de 2015, Francisco pede para que as paróquias, comunidades religiosas, monastérios e santuários de toda Europa recebam uma família de refugiados. E exorta aos cristãos que diante da tragédia de milhares de refugiados, a Igreja deve "dar-lhes uma esperança concreta. Não dizer apenas: 'Coragem, paciência!...'. A esperança cristã é combativa, com a tenacidade de quem caminha rumo a uma meta segura". ${ }^{37}$

Outro gesto profético de Francisco que comoveu o mundo foi no dia 6 de novembro de 2013. O abraço do Papa em Riva, um italiano que sofre de neurofibromatose, uma doença genética que pode causar deformidade na pele. ${ }^{38}$ Aquele abraço foi um verdadeiro gesto de acolhida, para expressar o amor de Cristo para com todos os enfermos. Este abraço representa tantos outros abraços de Francisco, num sinal de acolhida e compaixão, o Papa deu visibilidade aos "exilados ocultos", "a quem o preconceito retira o que lhes é de direito: dignidade, trabalho, o que pode levá-los a sentimentos de desesperança". ${ }^{39}$

\footnotetext{
${ }^{35}$ CENTOFANTI, S., Esmolaria Apostólica, a caridade silenciosa do Papa.

${ }^{36}$ FRANCISCO, PP., Santa Missa pelas vítimas dos naufrágios.

${ }^{37}$ FRANCISCO, PP., Angelus.

${ }^{38}$ TERRA, Homem desfigurado lembra do encontro com o Papa.

${ }^{39}$ SOUZA, L., A pessoa com deficiência no Pontificado do Papa Francisco, p. 96.
} 


\subsection{Ecumênico e inter-religioso}

Outros gestos proféticos de Francisco estão relacionados ao diálogo ecumênico e inter-religioso. O Papa não limita este diálogo apenas com discursos cordiais e teológicos, mas se utiliza de atos cheios de significados para alcançar a sonhada unidade. Em continuidade com o diálogo iniciado por seus predecessores, Francisco se reuniu em Jerusalém com o Patriarca de Constantinopla, Bartolomeu I, para repetir o abraço histórico entre o Papa Paulo VI e o Patriarca Atenágoras ocorrido em 5 de janeiro de 1964. Naquela ocasião, o encontro foi o símbolo da retomada do diálogo entre as Igrejas Católica e Ortodoxa. Como sinal de um profícuo diálogo mantido pela Igreja de Roma e a Igreja de Constantinopla, na busca da superação das diferenças e pelo desejo de construir um futuro de plena comunhão, em 2019, o Santo Padre presenteia Bartolomeu I com algumas relíquias do apóstolo São Pedro, um fragmento dos ossos de Pedro para que fossem colocados ao lado das relíquias do Apóstolo André. ${ }^{40}$

Outro momento histórico, aconteceu em 2016, Francisco e o Patriarca ortodoxo russo Kirill se encontraram em Cuba, foi o primeiro encontro dos líderes das duas igrejas após o cisma de 1054. No encontro, no aeroporto de Havana, eles se abraçaram e Francisco exclamou: "Finalmente". ${ }^{41}$ Durante o voo, Francisco disse aos jornalistas: "Foi uma conversação entre irmãos. Pontos claros, que preocupam a ambos, falamos deles. Com toda a franqueza. Eu sentime diante de um irmão, e também ele me disse o mesmo. Antes de tudo, dois bispos que falam da situação das suas Igrejas". ${ }^{42}$

Em direção às Igrejas da Reforma, Papa Francisco também continuou o diálogo iniciado por seus predecessores, e participou das comemorações do V centenário da Reforma Protestante na visita apostólica à Suécia em 2016. No seu discurso, o Papa reconheceu que a Reforma tinha contribuído para atribuir maior centralidade às Sagradas Escrituras na vida da Igreja. E afirma também que pela ocasião da comemoração da Reforma, católicos e luteranos tem "uma nova oportunidade para acolher um percurso comum, que se foi configurando ao longo dos últimos cinquenta anos no diálogo ecumênico". ${ }^{43}$ E continua dizendo: "Temos a possibilidade de reparar um momento crucial da nossa

\footnotetext{
${ }^{40}$ CAPPELI, B.; FRACCALVIERI, B., As relíquias de São Pedro.

${ }^{41}$ AGÊNCIA EFE, Papa chega a Cuba para encontro histórico com patriarca ortodoxo.

${ }^{42}$ FRANCISCO, PP., Palavras do Santo Padre durante o voo Cuba-México.

${ }^{43}$ FRANCISCO, PP., Oração ecumênica na Catedral Luterana de Lund.
} 
história, superando controvérsias e mal-entendidos que impediram frequentemente de nos compreendermos uns aos outros". ${ }^{44}$

O ideal ecumênico de Francisco é revelado em 28 de julho de 2014, durante o seu discurso em uma comunidade evangélica pentecostal na cidade de Caserta, na Itália. Neste encontro, ele apresenta a imagem de um poliedro como símbolo da unidade, mesmo formado por diversas partes é uma única figura geométrica. ${ }^{45}$ No caminho ecumênico, é o Espírito Santo que realiza a unidade diante da diversidade, cada Igreja tem o seu carisma: "é neste caminho que nós cristãos fazemos aquilo a que chamamos com o nome teológico ecumenismo: procuremos fazer com que esta diversidade seja mais harmonizada pelo Espírito Santo e se torne unidade". ${ }^{46}$

Francisco sublinha ainda que o caminho ecumênico iniciado por João XXIII e continuado por Paulo VI, João Paulo II e Bento XVI, permite aprofundar o próprio ministério petrino que favorece o diálogo com todos os crentes em Cristo. E que a unidade é fruto de um caminho conduzido pelo Espírito Santo. E exorta: Cristo não pode estar dividido! Esta certeza deve incentivar-nos e suster-nos a continuar, com humildade e confiança, o caminho para o restabelecimento da plena unidade visível entre todos os crentes em Cristo". ${ }^{47}$

O diálogo com muçulmanos e judeus também foram acompanhados de gestos proféticos. Francisco foi o primeiro Papa a visitar os Emirados Árabes Unidos. Durante a visita disse: "Estou aqui como um irmão" ${ }^{48}$ e junto do GrãoImã de Al-Azhar publicaram uma "Declaração Comum sobre a Fraternidade Humana em prol da Paz Mundial e da convivência comum" ${ }^{49} \mathrm{Na}$ viagem para a Terra Santa, diante do Muro das Lamentações, Francisco protagonizou um ato que foi chamado de "abraço das três religiões". ${ }^{50}$ Diante do Muro, o Papa abraçou o rabino judeu Abraham Skorka e o muçulmano Ombar Abboud, ambos são amigos e eram próximos ainda quando Francisco era o arcebispo de

44 FRANCISCO, PP., Oração ecumênica na Catedral Luterana de Lund.

${ }^{45}$ S. Pié-Ninot destaca que: "A originalidade e a novidade mais marcantes de Francisco é o uso que faz da imagem geométrica do poliedro para expressar a relação entre realidades opostas e contrastadas, sempre ficando claro que deve haver uma unidade profunda no núcleo essencial da fé que é Jesus Cristo morto e ressuscitado" (PIÉ-NINOT, S., La eclesiología del Papa Francisco, p. 279).

${ }^{46}$ FRANCISCO, PP., Discurso na Igreja Pentecostal da Reconciliação.

${ }^{47}$ FRANCISCO, PP., Homilia na Basílica de São Paulo Extra-muros.

${ }^{48}$ FRANCISCO, PP., Discurso no encontro inter-religioso.

${ }^{49}$ FRANCISCO, PP; AL-TAYYEB, A., Documento sobre a fraternidade humana em prol da Paz Mundial e da convivência comum.

${ }^{50} \mathrm{O}$ PAPA Francisco protagoniza emotivo abraço com judeu e muçulmano diante do Muro das Lamentações. 
Buenos Aires. E nesta mesma viagem, indo para a Belém, território palestino, Papa Francisco muda o roteiro oficial para rezar em silêncio no muro que separa Belém de Jerusalém. Este muro é visto pelos palestinos como um símbolo da opressão imposta por Israel ao território palestino. Como um gesto profético, Francisco reza em silêncio, logo depois de ter feito um convite, dentro da cidade de Belém, para que as autoridades palestinas e israelenses se unissem a ele em oração pela paz. ${ }^{51}$

A paz é um pedido constante diante dos líderes religiosos e de Estado, por diversas vezes pediu a superação da violência, diante dos conflitos entre as nações. E assim, comoveu o mundo depois da realização de um retiro espiritual para as autoridades civis e eclesiásticas do Sudão do Sul. Este retiro realizado no Vaticano foi uma proposta conjunta da Igreja Anglicana e da Igreja Católica para contribuir com as lideranças do país no processo de reconciliação e de paz do povo do Sudão do Sul. No final do encontro, o Papa beijou os pés dos líderes do país como uma súplica pela reconciliação e pela paz. ${ }^{52}$ Diante do gesto de Francisco, o Arcebispo anglicano, Justin Welby disse aos líderes africanos: "Escutamos o apelo profético de um Cristo. Agora fazemos de vós embaixadores da paz". ${ }^{53}$

\subsection{Ecológico}

A última categoria que apresentamos dos atos proféticos de Francisco é a defesa por uma ecologia integral. O seu posicionamento a favor do meio ambiente assume a força de um ato profético pela importância que ocupa em seu magistério. Em 2015, o Papa Francisco publicou a encíclica Laudato Si'. Este é o primeiro documento pontifício totalmente dedicado à questão ecológica. Assim, o Papa insere oficialmente os temas do meio-ambiente, sustentabilidade e cuidado da natureza na Doutrina Social da Igreja.

Diante da crise socioambiental de nosso tempo, Francisco expressa uma concepção ecológica do bem comum. A proteção e o cuidado com a casa comum é uma defesa do próprio homem e de sua dignidade. Ele recorda que o ser humano "possui uma dignidade especial, não podemos deixar de considerar os efeitos da degradação ambiental, do modelo atual de desenvolvimento e da cultura do descarte sobre a vida das pessoas". ${ }^{54}$

\footnotetext{
${ }^{51}$ FRANCISCO, PP., Regina Caeli.

52 JOSÉ, S., O Papa beija os pés dos líderes do Sudão do Sul pela paz.

${ }^{53}$ D'AVILLEZ, F., Papa beija os pés a líderes do Sudão do Sul e pede que não regressem à guerra.

${ }^{54}$ LS 43.
} 
Em sua visita apostólica ao Peru, em 2018, Francisco quis se encontrar com os povos da Amazônia. Ao ver de perto o "rosto amazônico" da Igreja, denunciou as inúmeras ameaças que o território amazônico sofre e a missão da Igreja de não fechar os olhos diante da injustiça e dos povos vulneráveis:

Nunca os povos originários amazônicos estiveram tão ameaçados nos seus territórios como o estão agora. A Amazónia é uma terra disputada em várias frentes: por um lado, a nova ideologia extrativa e a forte pressão de grandes interesses económicos cuja avidez se centra no petróleo, gás, madeira, ouro e monoculturas agroindustriais; por outro, a ameaça contra os vossos territórios vem da perversão de certas políticas que promovem a "conservação" da natureza sem ter em conta o ser humano, nomeadamente vós irmãos amazónicos que a habitais. ${ }^{55}$

Diante disso, Francisco convocou um sínodo para Amazônia, como um gesto profético em defesa ao ecossistema, às comunidades ribeirinhas e indígenas. Durante o Sínodo que aconteceu em outubro de 2019 no Vaticano, os padres sinodais escutaram atentamente os testemunhos de inúmeras pessoas que dedicam a sua vida a favor das comunidades amazônicas. Em um encontro de partilha, reflexão e oração, o Sínodo foi concluído com a elaboração do Documento final como um sinal de esperança de novos caminhos de presença, evangelização e diálogo intercultural da Igreja na Amazônia. ${ }^{56} \mathrm{E}$ em fevereiro de 2020, o Papa Francisco publica a Exortação Apostólica Pós-Sinodal Querida Amazônia formulada em quatro sonhos: ${ }^{57}$

Sonho com uma Amazônia que lute pelos direitos dos mais pobres, dos povos nativos, dos últimos, de modo que a sua voz seja ouvida e sua dignidade promovida. Sonho com uma Amazônia que preserve a riqueza cultural que a caracteriza e na qual brilha de maneira tão variada a beleza humana. Sonho com uma Amazônia que guarde zelosamente a sedutora beleza natural que a adorna, a vida transbordante que enche os seus rios

\footnotetext{
${ }^{55}$ FRANCISCO, PP., Encontro com os povos da Amazônia.

${ }^{56}$ SÍNODO DOS BISPOS PARA A REGIÃO PAN-AMAZÔNICA, Documento final do Sínodo para a Amazônia.

57 J. Martins Filho destaca que: “A metáfora do sonho, utilizada pelo papa na estruturação da Exortação Pós-Sinodal, ajuda-nos a outra vez conceber a tonalidade esperançosa impressa por Francisco em seu texto. Muitos esperavam um texto definitivo, resolutório de todas as conflitualidades postas em jogo pela experiência sinodal. Francisco, ao contrário, colocando-se como um irmão da humanidade inteira, especialmente no caminho de resguardo da ecologia, pondo-se, "humildemente", a "formular quatro grandes sonhos" que a Amazônia lhe inspirara" (MARTINS FILHO, J., Um sonho ecológico para a Igreja, p. 117).
} 
e as suas florestas. Sonho com comunidades cristãs capazes de se devotar e encarnar de tal modo na Amazônia, que deem à Igreja rostos novos com traços amazônicos. ${ }^{58}$

Para Francisco, a articulação da questão ecológica com a questão social é fundamental na defesa da dignidade humana. O tema é extenso e Francisco não se omite diante de uma crise que tende aumentar a pobreza, a desigualdade social e o extermínio das populações mais frágeis. Como uma voz profética no meio do deserto, Francisco convida o mundo a uma conversão ecológica, isto é, a partir do encontro com Cristo, o cristão também deve transformar a sua relação com o mundo, de modo que assuma a sua responsabilidade de cuidar da obra da criação. ${ }^{59}$

\section{Conclusão}

Apreciar os atos do Papa Francisco em perspectiva litúrgico-sacramental é adentrar em um novo caminho de reflexão sobre este pontificado. Os gestos de Francisco possuem uma força de expressão maior do que as palavras contidas em seus discursos. Estes atos estão em linha de continuidade com as ações simbólicas dos profetas de Israel e de Jesus que foram prolongadas na vida da Igreja, por meio dos sacramentos. Da mesma forma que o que se verificou na missão dos profetas de Israel e, particularmente, na existência de Jesus, se reproduz também nos gestos rituais que a comunidade cristã celebrava, podemos identificar a presença destes atos proféticos no pontificado do Papa Francisco.

Além disso, identificamos o Papa Francisco como um mistagogo, tal como os grandes mestres da mistagogia antiga, que conduziam os cristãos para a vivência dos mistérios, Francisco visibiliza o Reino de Deus, anuncia a conversão dos costumes e aponta para a vinda iminente de Cristo. O seu ministério é marcado pela visibilidade do antigo axioma lex orandi, lex credendi, lex agendi, e de forma incansável anuncia com sua vida, palavras e gestos, o mistério salvífico de Cristo.

Como atos proféticos, os gestos de Francisco transcendem no tempo. É possível que os seus significados não se esgotem no momento de sua realização, mas continuem a falar durante muito tempo até que se compreenda a força de sua expressão. Se as palavras são esquecidas pela brevidade do tempo, os atos

${ }^{58}$ Querida Amazônia, 7.

${ }^{59}$ LS 216-221. 
permanecem como sinal vivo de uma mensagem que ainda tem o que dizer ao mundo.

Neste ano de 2020, que o mundo sofre com uma pandemia de proporção planetária, Francisco comoveu o mundo quando saiu do Vaticano e percorreu algumas ruas de Roma a pé no dia que foi rezar diante do ícone de Nossa Senhora Salus Populi Romani e do Crucifixo milagroso na Igreja de São Marcelo ${ }^{60}$ E depois, o mundo todo o acompanhou na transmissão da oração que realizou na Praça de São Pedro vazia pelo fim da pandemia. O homem vestido de branco, sozinho na grandiosa praça, era visto por milhões de pessoas de diversas nações, explicando o sentido do mistério da fé. É ele o profeta-mistagogo que conduz a Igreja e o mundo para o encontro com o mistério da salvação:

O início da fé é reconhecer-se necessitado de salvação. Não somos autossuficientes, sozinhos afundamos: precisamos do Senhor como os antigos navegadores, das estrelas. Convidemos Jesus a subir para o barco da nossa vida. Confiemos-Lhe os nossos medos, para que Ele os vença. Com Ele a bordo, experimentaremos - como os discípulos - que não há naufrágio. Porque esta é a força de Deus: fazer resultar em bem tudo o que nos acontece, mesmo as coisas ruins. Ele serena as nossas tempestades, porque, com Deus, a vida não morre jamais. ${ }^{61}$

\section{Referências bibliográficas}

AGÊNCIA EFE. Papa chega a Cuba para encontro histórico com patriarca ortodoxo. Época, Rio de Janeiro, 12 fev. 2016. Disponível em: $<$ https://epocanegocios.globo.com/Mundo/noticia/2016/02/papa-chega-cubapara-encontro-historico-com-patriarca-ortodoxo.html.>. Acesso em 12 jul. 2020. BÍBLIA de Jerusalém. São Paulo: Paulus, 1995.

BENTO XVI, PP. Exortação Apostólica Sacramentum Caritatis sobre a Eucaristia, fonte e ápice da vida e da missa da Igreja. São Paulo: Paulinas, 2007.

BOSELLI, G. O sentido espiritual da liturgia. Brasília: Edições CNBB, 2014. CAPPELI, B.; FRACCALVIERI, B. As relíquias de São Pedro: dom para a unidade da Igreja. Vatican News, Roma, 15 set. 2019. Disponível em:

${ }^{60}$ VATICAN NEWS, As duas orações do Papa para invocar o "fim da pandemia".

${ }^{61}$ FRANCISCO, PP., Momento extraordinário de oração em tempo de epidemia. 
$<$ https://www.vaticannews.va/pt/papa/news/2019-09/papa-francisco-reliquiassao-pedro-bartolomeu-unidade-igreja.html>. Acesso em: 10 jul. 2020.

CASULA, L. Rostos, gestos e lugares: A cristologia do Papa Francisco. Brasília: Edições CNBB, 2018.

CENTOFANTI, S. Esmolaria Apostólica, a caridade silenciosa do Papa. Vatican News, Roma, 16 mai. 2019. Disponível em: $<$ https://www.vaticannews.va/pt/vaticano/news/2019-05/esmolariaapostolica-papa-caridade.html>. Acesso em: 11 jul. 2020.

CONGREGAÇÃO PARA O CULTO DIVINO E A DISCIPLINA DOS SACRAMENTO. Decreto In Missa In Cena Domini. Disponível em: $<$ https://www.vatican.va/roman_curia/congregations/ccdds/documents/rc_con_cc dds_doc_20160106_decreto-lavanda-piedi_po.html >. Acesso em: 11 jul. 2020 .

CONCÍLIO VATICANO II. Constituição Sacrosanctum Concilium sobre a Sagrada Liturgia. In: KLOPPENBURG, B. Compêndio do Vaticano II: Constituições, decretos e declarações. Petrópolis: Vozes, 2000. p. 259-308.

D’AVILLEZ, F. Papa beija os pés a líderes do Sudão do Sul e pede que não regressem à guerra. Renascença, Lisboa, 11 abr. 2019. Disponível em: $<$ https://rr.sapo.pt/2019/04/11/religiao/papa-beija-os-pes-a-lideres-do-sudao-dosul-e-pede-que-nao-regressem-a-guerra/noticia/147718>. Acesso em 13 jul. 2020.

ELLIS, P. Jeremias. In: BERGANT, D.; KARRIS, R. (Orgs.). Comentário bíblico. São Paulo: Loyola, 2008. p. 45-66. v. II.

FLORISTÁN, C. Pastoral litúrgica. In: BOROBIO, D. (Org.). A celebração na igreja: Liturgia e sacramentologia fundamental. São Paulo: Loyola, 1990. p. 425-462.

FRANCISCO, PP. Angelus. Roma, 6 set. 2015. Disponível em: $<$ http://www.vatican.va/content/francesco/es/angelus/2015/documents/papafrancesco_angelus_20150906.html $>$. Acesso em 12 jul. 2020.

FRANCISCO, PP. Carta Encíclica Laudato Si’. Brasília: Edições CNBB, 2015.

FRANCISCO, PP. Discurso aos participantes na assembleia plenária da congregação para o culto divino e a disciplina dos sacramentos. Roma, 14 fev. $2019 . \quad$ Disponível em: $<$ http://www.vatican.va/content/francesco/pt/speeches/2019/february/docume nts/papa-francesco_20190214_cong-culto-divino.html>. Acesso em 10 jul. 2020. 
FRANCISCO, PP. Discurso aos participantes na $6^{\text {a }}$ semana litúrgica nacional. Roma, 24 ago. 2017. Disponível em: $<$ http://www.vatican.va/content/francesco/pt/speeches/2017/august/document s/papa-francesco_20170824_settimana-liturgica-nazionale.html> Acesso em 13 jul. 2020.

FRANCISCO, PP. Discurso na Igreja Pentecostal da Reconciliação. Caserta, 28 jul. 2014. Disponível em: $<$ http://www.vatican.va/content/francesco/pt/speeches/2014/july/documents/papa -francesco_20140728_caserta-pastore-traettino.html>. Acesso em 12 jul. 2020.

FRANCISCO, PP. Discurso no encontro inter-religioso. Abu Dhabi, 4 fev. 2019.

Disponível

em:

$<$ http://www.vatican.va/content/francesco/pt/speeches/2019/february/docume nts/papa-francesco_20190204_emiratiarabi-incontrointerreligioso.html >. Acesso em: 13 jul. 2020.

FRANCISCO, PP. Encontro com os povos da Amazônia. Puerto Maldonado, 19 jan. 2018. Disponível em: $<$ http:/www.vatican.va/content/francesco/pt/speeches/2018/january/documen ts/papa-francesco_20180119_peru-puertomaldonado-popoliamazzonia.html $>$. Acesso em: 13 jul. 2020.

FRANCISCO, PP. Exortação Apostólica Evangelii Gaudium. São Paulo: Paulinas, 2013.

FRANCISCO, PP. Exortação Apostólica Pós-Sinodal Querida Amazônia. São Paulo: Paulinas, 2020.

FRANCISCO, PP. Homilia na Basílica de São Paulo Extra-muros. Roma, 25 jan 2014. Disponível em: $<$ http://www.vatican.va/content/francesco/pt/homilies/2015/documents/papafrancesco_20150125_vespri-conversione-san-paolo.html>. Acesso em 12 jul. 2020. FRANCISCO, PP. Misericordiae Vultus. São Paulo: Paulinas, 2015.

FRANCISCO, PP. Momento extraordinário de oração em tempo de epidemia. Roma, 27 mar. 2020. Disponível em: $<\mathrm{http} / /$ www.vatican.va/content/francesco/pt/homilies/2020/documents/papafrancesco_20200327_omelia-epidemia.html>. Acesso em 12 jul. 2020.

FRANCISCO, PP. Oração ecumênica na Catedral Luterana de Lund. Lund, 31 out. 2016.2 Disponível em: 
$<$ http://www.vatican.va/content/francesco/pt/homilies/2016/documents/papafrancesco_20161031_omelia-svezia-lund.html>. Acesso em 13 jul. 2020.

FRANCISCO, PP. Palavras do Santo Padre durante o voo Cuba-México, 12 fev. 2016. Disponível em: $<$ http://www.vatican.va/content/francesco/pt/speeches/2016/february/docume nts/papa-francesco_20160212_cuba-messico-saluto-giornalisti.html>. Acesso em 12 jul. 2020.

FRANCISCO, PP. Regina Caeli. Belém, 25 mai. 2014. Disponível em: $<\mathrm{http}$ //www.vatican.va/content/francesco/pt/angelus/2014/documents/papafrancesco_regina-coeli-terra-santa_20140525.html >. Acesso em: 12 jul. 2020.

FRANCISCO, PP. Santa Missa pelas vítimas dos naufrágios. Lampedusa, 8 jul. 2013. Disponível em: $<$ http://www.vatican.va/content/francesco/pt/homilies/2013/documents/papafrancesco_20130708_omelia-lampedusa.html >. Acesso em: 13 jul. 2020.

FRANCISCO, PP; AL-TAYYEB, A. Documento sobre a fraternidade humana em prol da Paz Mundial e da convivência comum. Abu Dahbi, 4 fev. $2019 . \quad$ Disponível em: $<$ http://www.vatican.va/content/francesco/pt/travels/2019/outside/documents/ papa-francesco_20190204_documento-fratellanza-umana.html $>$. Acesso em 12 jul. 2020.

GUIMARÃES, P. B. Os sacramentos como atos eclesiais e proféticos: Um contributo ao conceito dogmático de sacramento à luz da exegese contemporânea. Roma: Editrice Pontificia Università Gregoriana, 1998.

JOSÉ, S. O Papa beija os pés dos líderes do Sudão do Sul pela paz. Vatican News, Roma, 12 abr. 2019. Disponível em: $<$ https://www.vaticannews.va/pt/papa/news/2019-04/papa-francisco-sudaosul-beija-pes.html>. Acesso em: 13 jul. 2020.

KASPER, W. La sfida della misericórdia. Magnano: Qiqajon, 2015.

MARTINS FILHO, J. Um sonho ecológico para a Igreja: o magistério de Francisco da Laudato Si' ao Sínodo para a Amazônia. Atualidade Teológica, v. 24, n. 64, p. 104-126, jan./abr. 2020. Disponível em: $<$ https://www.maxwell.vrac.puc-rio.br/47880/47880.PDF>. Acesso em: 13 jul. 2020. DOI: https://doi.org/10.17771/PUCRio.ATeo.47880 
MICKENS, R. Papa Fracisco escolhe novos cardeais que vêm da periferia. Revista IHU, Porto Alegre, 5 jan. 2015. Disponível em: $<$ http://www.ihu.unisinos.br/169-noticias/noticias-2015/538735-papa-franciscoescolhe-novos-cardeais-que-vem-da-periferia $>$. Acesso em: 12 jul. 2020.

MONTEIRO, A. B. Os sacramentos como continuação dos atos de Cristo na Igreja. Rio de Janeiro, 2017. 101p. Dissertação. Faculdade de Teologia, Pontifícia Universidade Católica do Rio de Janeiro.

MOTTU, H. Il gesto e la parola. Magnano: Qiqajon, 2007.

O PAPA Francisco protagoniza emotivo abraço com judeu e muçulmano diante do Muro das Lamentações. ACI Digital, Roma, 26 mai. 2014. Disponível em: $<$ https://www.acidigital.com/noticias/o-papa-francisco-protagoniza-emotivoabraco-com-judeu-e-muculmano-diante-do-muro-das-lamentacoes-13423>. Acesso em: 12 jul. 2020.

PAULO VI, PP. Exortação Apostólica Evangelii Nuntiandi. São Paulo: Paulinas, 2011.

PIÉ-NINOT, S., La eclesiología del Papa Francisco. Atualidade Teológica, v. 22, n. 59, p. 255-286, mai./ago. 2018. Disponível em: < https://www.maxwell.vrac.puc-rio.br/34471/34471.PDFXXvmi=>. Acesso em: 13 jul. 2020. DOI: https://doi.org/10.17771/PUCRio.ATeo.34471

RAD, G. Teologia do Antigo Testamento. São Paulo: ASTE / Targumim, 2006.

REPOLE, R. O sonho de uma Igreja evangélica: a eclesiologia do Papa Francisco. Brasília: Edições CNBB, 2018.

ROSATO, P. Introdução à teologia dos sacramentos. São Paulo: Loyola, 2006.

SARTORE, D. Mistagogia. In: SARTORE, D.; TRIACCA, A. M.; CIBIEN, C. (Orgs.). Dizionari San Paolo. Liturgia. Milano: San Paolo, 2001. p. 1208-1215.

SINODO DEI VESCOVI. Relazione finale del sinodo dei vescovi. Aggiornamenti sociali, v. 37, n. 1, p. 73, gen. 1986. Disponível em: $<$ https://www.aggiornamentisociali.it/articoli/relazione-finale-del-sinodo-deivescovi/>. Acesso em: 12 jul. 2020.

SÍNODO DOS BISPOS PARA A REGIÃO PAN-AMAZÔNICA. Documento final do Sínodo para a Amazônia. Disponível em: $<\mathrm{http}$ ://www.synod.va/content/sinodoamazonico/pt/documentos/documentofinal-do-sinodo-para-a-amazonia.html>. Acesso em 13 jul. 2020. 
SOUZA, L. A pessoa com deficiência no Pontificado do Papa Francisco: um olhar misericordioso. Rio de Janeiro, 2016. 124p. Dissertação. Departamento de Teologia, Pontifícia Universidade Católica do Rio de Janeiro.

TABORDA, F. Uma eucaristia viva para uma Igreja viva: reflexões em torno a um discurso do Papa Francisco. Atualidade Teológica, v. 22, n. 58, p. 91-119, jan./abr. 2018. Disponível em: <https://www.maxwell.vrac.pucrio.br/32831/32831.PDFXXvmi=>. Acesso em: 13 jul. 2020. DOI: https://doi.org/10.17771/PUCRio.ATeo.32831

TERRA. Homem desfigurado lembra do encontro com o Papa. Portal Terra, 19 nov. 2013. Disponível em: $<$ https://www.terra.com.br/noticias/mundo/europa/homem-desfiguradolembra-encontro-com-o-papa-pensei-que-iamorrer,ea73290794072410VgnVCM20000099cceb0aRCRD.html>. Acesso em: 13 jul. 2020.

TRIACCA, A. M. Rinnovamento liturgico. In: SARTORE, D.; TRIACCA, A. M.; CIBIEN, C. (Orgs.). Dizionari San Paolo. Liturgia. Milano: San Paolo, 2001. p. 1654-1666.

VATICAN NEWS. As duas orações do Papa para invocar o "fim da pandemia". Vatican News, Roma, 15 mar. 2020. Disponível em: $<$ https://www.vaticannews.va/pt/papa/news/2020-03/oracoes-papa-franciscoinvocar-fim-pandemia-coronavirus.html $>$. Acesso em: 12 jul. 2020.

Anderson Batista Monteiro

Doutorando em Teologia pela Pontifícia Universidade Católica do Rio de Janeiro Rio de Janeiro / RJ - Brasil E-mail: andersonbatista2207@gmail.com

Recebido em: 23/08/2020

Aprovado em: 28/06/2021 